\title{
Russian Preference for Red Printed Cotton from Central Asia and Industrialization
}

\section{Masachika Shiotani}

\begin{tabular}{|c|l|}
\hline Citation & Asian Review of World Histories. 9(1); 4-23. \\
\hline Issue Date & $2020-12-11$ \\
\hline Type & Journal Article \\
\hline Textversion & Author \\
\hline Relation & $\begin{array}{l}\text { The following article has been accepted by Asian Review of World Histories. } \\
\text { This is the accepted manuscript version. The final, published version is available } \\
\text { attps://doi.org/10.1163/22879811-12340083. } \\
\text { Please cite only the published version. }\end{array}$ \\
\hline doi & \begin{tabular}{l}
$10.1163 / 22879811-12340083$ \\
\hline
\end{tabular} \\
\hline
\end{tabular}

Self-Archiving by Author(s)

Placed on: Osaka City University Repository 


\title{
Russian Preference for Red Printed Cotton from Central Asia and Industrialization ${ }^{1}$
}

\author{
Masachika Shiotani \\ Faculty of Economics, Osaka City University \\ Osaka, Japan \\ shiotani@econ.osaka-cu.ac.jp
}

\begin{abstract}
The industrialized countries had unfavorable natural circumstances in comparison with Asia. But, as Europe had a preference for Indian commodities, it tried to find ways to importsubstitute them. As a result, Europe created science and technology, constructed the transatlantic trade system and import-substituted Indian printed cotton. As Russia also tried to import-substitute "red" printed cotton from Central Asian, it achieved its early industrialization. Thus, it can be concluded that when a certain national ongoing appreciation or preference persists for a long time (in this case, three centuries), even if circumstances are unfavorable, obstacles can eventually be overcome and the object in question obtained, even if indirectly. In the case of Russia, their preference for "red" printed cotton from Central Asia promoted the modern cotton industry.
\end{abstract}

\section{Keywords}

${ }^{1}$ I would like to express my thanks to the anonymous reviewers for their comments and suggestions, which have helped me to improve this document. This manuscript is newly edited and is based on works I have previously published in Japanese and Russian (Shiotani 2000, 2009, 2014). 
chemistry, commercial network, nature, red printed cotton, steam engine, modernity

\section{The Transformation of Long-Distance Trade}

\section{Before the Era of Transatlantic Trade}

Before the era of transatlantic trade, printed cotton was produced only in specific regions using raw materials including cotton and dye. Both materials can be cultivated and/or manufactured only in regions with certain climatic conditions. Cotton was originally cultivated in India, and printed cotton manufactured in the country was subsequently transplanted eastward and westward (Kawakatsu 1991, 68). People across various regions attempted to cultivate cotton, but it could only be done in the region stretching between the latitudes of $30^{\circ}-40^{\circ}$ north and south of the equator. Printed cotton was produced in central Eurasia for a long time. Madder was grown specifically in Eurasia, and it was difficult to cultivate cotton and dye in any other location. Before industrialization, printed cotton had to be imported from Asia, as it was difficult to cultivate both items in Russia and Europe.

Before industrialization, activities pertaining to agriculture and manufacturing were adapted to natural conditions. Peasants engaged in farm work from spring until fall, and in local cottage industries in winter. All work depended on the availability of natural energy (water and wind) and animal power (including men). Agricultural products and handicrafts were supplied to regional fairs, which were usually held near churches and monasteries. The duration of these fairs was decided according to the availability of animals (camel and horse) and the local natural conditions.

Merchant groups have long monopolized commercial networks in long-distance trade. Trade relays were also dominant; some merchants distributed commodities in a certain section and transferred them to counterparts in the next section. Long before trade commenced across the Atlantic Ocean, long-distance sea trade was carried out, but every 
major port supplied water and food to ships. As there were no major landmasses between Europe and America, ships crossing the Atlantic did not stop at ports. The start of trade across the Atlantic Ocean symbolized the decline of long-distance sea trade, as new, larger and stronger ships overshadowed older ones.

\section{After the Era of Transatlantic Trade}

Initially, the East India Company conducted trade with Asia primarily to buy spices. When they discovered Indian printed cotton, they began to import it to Europe, and demand for it increased dramatically. They first exported the locally printed Indian cotton directly to Europe. However, they later began to convey European tastes to Indian craftspeople, such as asking them to dye the cotton in ways that Europeans liked, and exported new commodities to Europe. Europe subsequently showed a trade deficit with Asia as this type of cotton became popular. Europe suppressed the import of Indian printed cotton to control the trade deficit and promoted efforts to find a substitute for the material. As it was difficult to cultivate cotton in Europe, Europeans began to import cotton yarn and textiles from the Middle East, and craftsmen began dying cotton cloth. As local manufacturers had no expertise in the dyeing technique, their attempts to imitate Indian printed cotton failed (Fukasawa 2007).

The dyeing technique for printed cotton was derived from ancient India. Thus, the cultivation of cotton and dye was adapted to the Indian climate and suited for the conditions there. The dyeing technique was improved through trial and error over centuries. Before industrialization, this manufacturing process depended on a skilled technique. Practical knowledge of the technique was passed to subsequent generations only through oral instructions. Europe endeavored to understand the Indian dyeing technique for years, without success. Finally, a French company invited skilled dyeing artisans from the Osman Empire to Marseille and observed their technique and acquired the necessary scientific knowledge. 
From a modern standpoint, the process of dyeing included a series of chemical reactions. Later, European companies applied chemistry to the dyeing process and further altered their technique, which then spread across Europe and became common knowledge.

The European cotton industry relied on its colonies and the Middle East to deliver cotton and dye. This helped them imitate Indian printed cotton and start manufacturing it locally. In this way, Europe responded to consumer demand. However, as sales of printed cotton grew, sales of local hemp and wool declined, so European countries restricted the dyeing of cotton textiles. Although dyeing of printed cotton declined in France, it continued in Alsace (Mulhouse) and England, in violation of governmental restrictions (Sano 1978, 214). The dyeing business in that region started to use copperplate engraving instead of woodblock printing and then moved on to roller printing machines (rotary copper). As a result, productivity of printed cotton increased. Although the natural conditions of Europe were unsuitable for cotton production, the import substitution of printed cotton was promoted. After Europe constructed long-distance sea trade systems to overcome its natural drawbacks, it succeeded in the import substitution of Indian printed cotton.

Printed cotton production in Europe was revolutionized after the introduction of the steam engine across industries. The steam engine was originally used to pump water from tunnels in mines. England then started to use it in the spinning and dyeing process and subsequently introduced it into other industries, and industrialization accelerated (Chapman 1985, 182). As coal (fossil fuel) was used to power steam engines, industries were now powered by fossil fuels. In the second half of the nineteenth century, American slaves and Russian serfs were emancipated due to the transformation (using fossil fuels instead of natural energy, such as water and wind as well as animals, including humans). As Europe improved technology and long-distance sea trade, it realized the mass production of cotton fabrics. The progress in Europe subsequently influenced industries in Russia. 


\section{Early Industrialization in Russia}

\section{Russia before Industrialization}

Before industrialization, the production of commodities was constrained by natural conditions. As Russia mainly experiences a cold climate, it was easy to cultivate wheat, rye, flax, and hemp, but not vegetables and fruits. The production of fur, tallow, and hemp cloth were suitable in Russian conditions, and Russian fur was a precious commodity internationally. Fur quality worsens in warm climates, so furs must be processed in cold weather, for which the conditions in Russia were best.

Russia was governed by the Mongol Empire from the fourteenth to the fifteenth century, and the principality of Moscow could not trade with Asia directly as the south region of Kazan belonged to the Empire. As Russia had no ports along the Baltic Sea in those days, it traded with Northern Europe through the Arhangerisk along the Volga River. At that time, Asia was a more important trade partner for Russia than Europe. Russia traded with Asia through Kazan Khan (Mongol Empire). Nizhny Novgorod was situated between Russia and the Mongol Empire; when Russians proceeded south from Nizhny Novgorod, they reached Kazan Khan, which was home to many Muslims (Komatsu 1983; Yamauchi 2009). The Makarievsk (later Nizhegorod) Fair in Nizhny Novgorod was where Russian merchants conducted trade with Asia before the advent of modern trade. Merchants sold Russian fur for Asian commodities at the fair (Bogoroditskaya 1989, 3).

Before modern trade developed, long-distance trade followed an annual cycle. Trade was planned, keeping in mind local climate and geography (Ostroukhov 1972, 220). Commodities were transported between Russia and Asia either by camels or ships. However, they could not be transported by ships in the winter when Russian rivers were frozen. Although camels were slower, they could traverse long distances and carry heavy loads. 
Camels were weaker during the molting season in summer and therefore they could not transport commodities. Thus, when merchants arranged caravans of camels, they avoided the summer months. When the Mongol Empire governed Russia, the latter could utilize the commercial network of the Empire in its trade with Asia.

Russia exported fur and metal products to Asia for a long time and in turn imported cotton and silk cloth and precious metals. Asian merchants played a pivotal role in boosting trade between Russia and Asia. The rulers of the Mongol Empire unified Asian merchants and controlled all the trade within the Empire, including Russia (Sugiyama 2010). After Russia gained independence from Mongol rule in 1552, it continued using their commercial networks.

As the climatic and geographic conditions were unsuitable for cotton cultivation in Russia, it had to import cotton fabrics, yarn, and woven cloth from Asia. Hence, Russia imported cotton fabrics from Central Asia since the sixteenth century. Because cotton fabrics were imported at that time, it was difficult for ordinary Russian people to obtain them. Those imported from Central Asia were mainly used by the ruling class. In the eighteenth century, Islamic merchants in Kazan started to work with dye artisans from Bukhara (Central Asia) and to import-substitute Central Asian red printed cotton along the Volga River due to high demand in Russia. Merchants began to import cotton yarn from Central Asia, weave and dye the cloth, and supply the red printed cotton at Russian fairs. As artisans increased the production of such cotton, Bukharan studios spread along the Volga River by the end of the eighteenth century and reached Ivanovo village (Vladimir province) (Solovyev and Boldyreva 1987, 4).

\section{Russia after Industrialization}

Many Russian orthodox churches were located near Vladimir province. As people engaged in 
the production of icons and manuscripts of the Bible, they supplied religious products to Russia. As hemp was cultivated in Vladimir province in the eighteenth century, printing on hemp cloth started. The dyeing technique reached the province in the second half of the eighteenth century, when production of Central Asian red printed cotton spread along the Volga River. Meanwhile, dye artisans from Ivanovo visited the region near St. Petersburg and learned German dyeing techniques. They subsequently became well-versed in dyeing techniques both from Central Asia and Europe. In due course, Vladimir province became the center of the Russian dyeing industry by the nineteenth century (Industriya 1910, 34). The artisans in Ivanovo replicated the hemp dyeing technique for cotton products in the second half of the eighteenth century and began to dye both Central Asian and Russian cotton cloth.

Russia developed its modern cotton industry by the end of the eighteenth century after importing cotton yarn and cloth from England. As the artisans in Vladimir province knew the basic dyeing technique, they bought Central Asian and English cotton yarn and began to produce colorful cheap printed cotton. It should be noted that English cotton yarn was cheaper than that from Central Asia because England had instituted mass production.

By the beginning of the nineteenth century, Russian artisans had perfected their dyeing technique, but it was still a skilled art. On the other hand, Europeans used applied science (chemistry) to standardize their dyeing technique, introducing chemical materials to the dyeing process, and they modernized the method of fixing colors on the cloth. Dyeing artisans in Vladimir learned the chemical dyeing method from Europeans who had migrated to Russia in the 1810s. They learned the "Turkey (Adrianople) red" and mechanized dyeing processes. This was the first known case of applying chemistry to dyeing in Russia. When the roller dyeing machine using rotary copper was introduced, people realized that dyeing using three colors at the same time shortened the time taken to complete the process. Productivity further increased after the steam engine was introduced to this process. The steam engine was 
also introduced to spinning mills and power looms in Russia in the nineteenth century.

When Russia imported raw cotton and dyestuffs from Europe, it applied European science and technology for modernization of its cotton industry. Before the introduction of the steam engine, it used energy from animals and natural sources (wind and water). However, after the steam engine was applied to production in the first half of the nineteenth century, its main energy source shifted to fossil fuel. Earlier, work was done during the day and was influenced by natural conditions, but commodity production was no longer restrained by the time of day and natural circumstances. Russia first wove cotton cloth from English cotton yarns and eventually succeeded in import substitution by the 1840s (Fig. 1) and began to produce its own cotton fabrics. The introduction of the steam engine helped increase cotton yarn production and the productivity of dyeing in Russia. The steam engine ensured that supply exceeded domestic demand, which meant there was surplus.

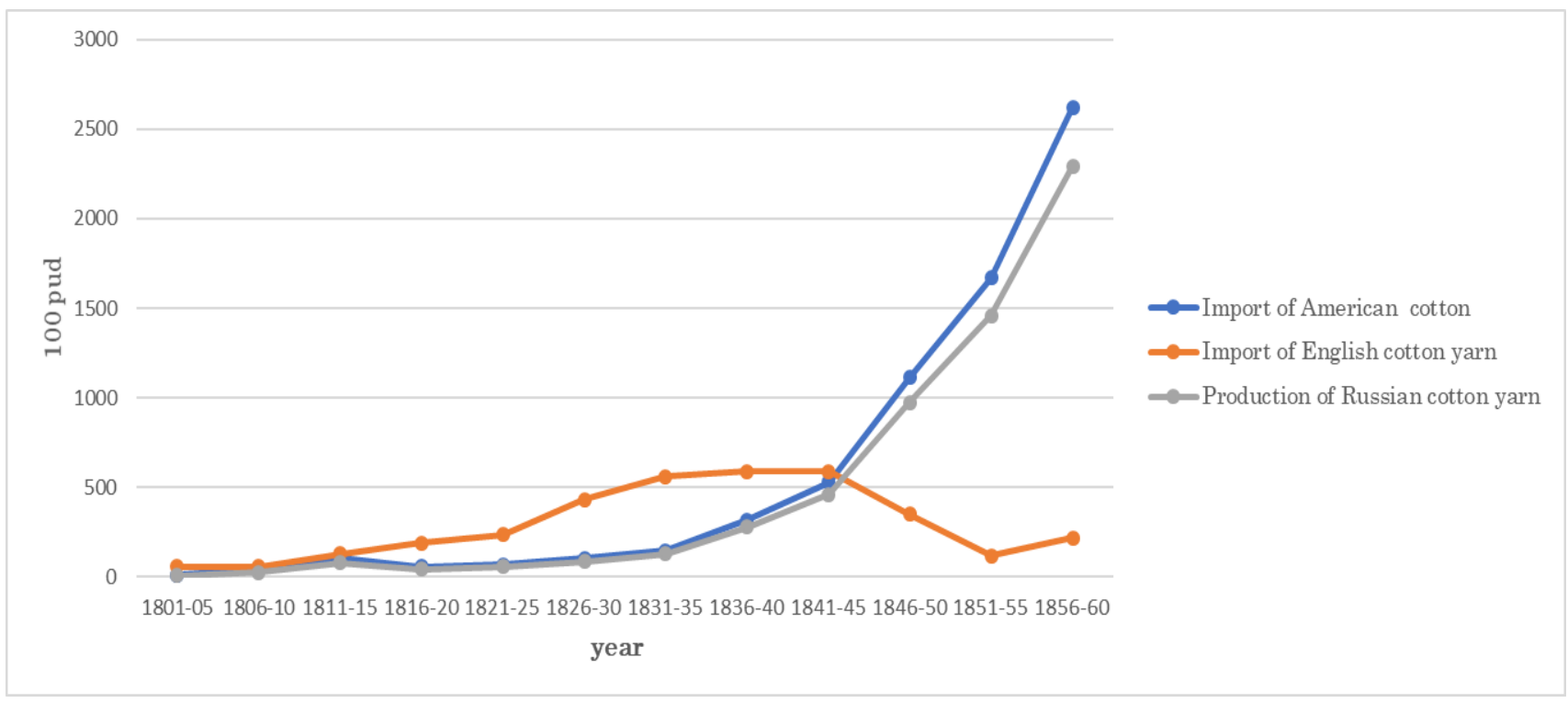

\section{Insert Figure1}

Figure 1. Imports of cotton and yarn and domestic production of cotton yarn, 18011860. Sources: Arima 1973, 119; Yatsunskiy 1979, 182.

Russia, which had a surplus of commodities, exported cotton fabrics to Asia through 
the commercial network of the neighboring commercial sphere (Fig. 2).

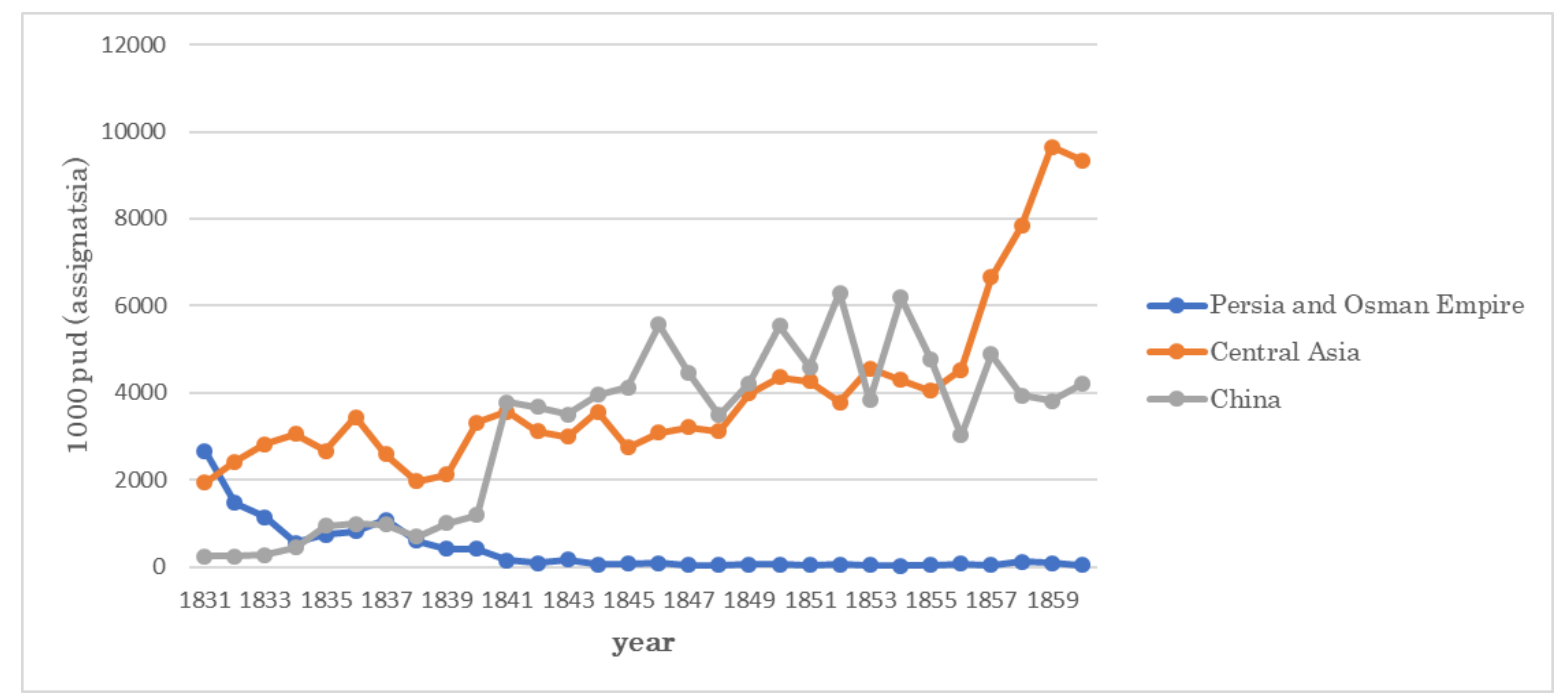

\section{Insert Figure 2}

Figure 2. Russian export of cotton fabrics to Asia, 1831-1860. Source: Departament vneshney torgovli, 1832-1861.

Ethnic merchants conducted trade between Russia and Asia (Fig. 3). While Armenian merchants carried out exports to Persia (Panossian 2006, 86), Bukharan merchants handled exports to Central Asia (Ziyaev 1983, 3). Shanxi merchants supervised exports to China (Silin 1947, 102). These ethnic merchants were dominant. While Armenian merchants controlled the distribution in Persian commerce, Bukharan merchants controlled it in the trade with Central Asia. Shanxi merchants governed the distribution in Chinese commerce. The commercial network of the Asian merchants was shaped over centuries. They organized their trading activities in a yearly cycle and relied on animals and natural conditions. These ethnic merchants exported Russian cotton fabrics to Asia through the Nizhegorod Fair, the largest fair in Russia in those days. 


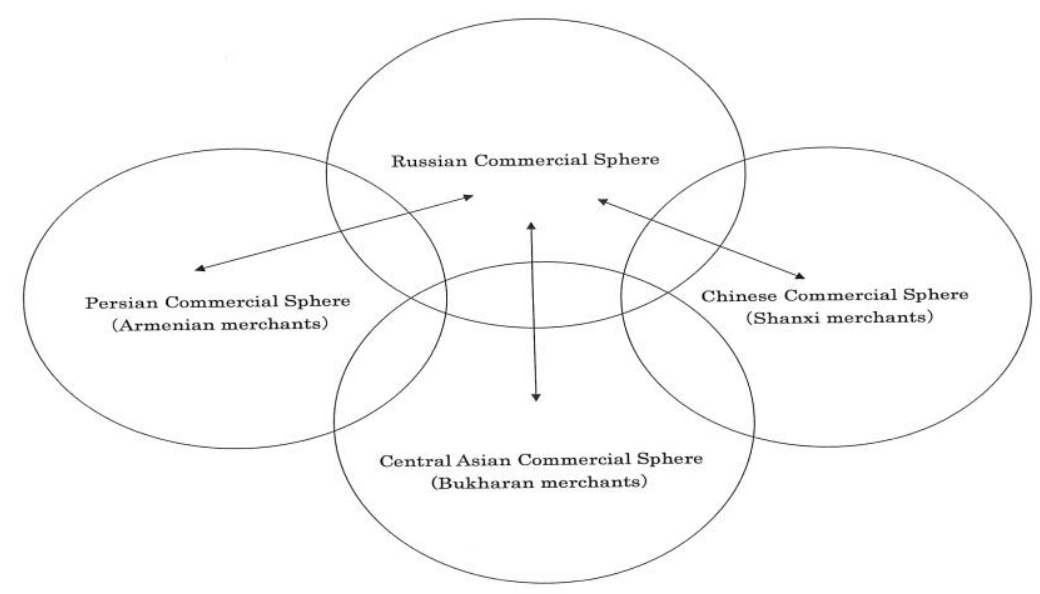

\section{Insert Figure 3}

Figure 3. Russian export of cotton fabrics to Asia, 1800-1860. Source: Shiotani 2014, 159.

\section{The Beginning of the Modern Era}

\section{Industrialization: Overcoming Nature}

After it became independent from the Mongol Empire, Russia began to utilize the European transatlantic trade and European science and technology. This enabled Russia to produce cotton fabrics and overcome the constraints of nature, leading to the development of its modern cotton industry (Yatsunsky 1974, 115).

When cheap Russian printed cotton reached domestic fairs, peasants started to use cotton fabrics. Initially, hemp cloth was only available in red and white, but as the dyeing process became cheaper, multiple colors were used. Products for Russian peasants included everyday clothes and those for special occasions. While cheap materials were used to make clothes that were worn every day, expensive materials were used to make the latter. Silk textiles were used to make special clothes as they were expensive. However, multicolored printed cotton made peasants feel "special." As printed cotton permeated peasants' lives, the market economy also included them. 
Long-distance overland trade was carried out in yearly cycles for many centuries (Shiotani 2019, 41-55). Russian fairs were also held in a yearly cycle. The Nizhegorod Fair, the largest in Russia, was held every summer. A yearly cycle was suitable for both fairs as well as the basic lives of peasants, who engaged in agriculture from spring to fall and made clothes in the winter. When Russia started the production of Central Asian red printed cotton in the eighteenth century, the process followed a yearly cycle. The task of weaving from cotton yarn was outsourced to peasants in the agricultural off-season. However, after the steam engine was added to the production process, and after fossil fuel became the main energy source, cotton fabrics could be produced all year round. When the quantity of Russian cotton fabrics exceeded domestic demand through innovation in production, surplus commodities appeared.

Although Russian surplus commodities were primarily exported to Persia, Central Asia, and China, they were most accepted in Central Asia. This was because the Bukharan merchants cooperated with Russian Muslims to exchange both commodities and information. Kazanese merchants easily cooperated with Bukharan merchants because they had a common language, Turkish, and religion, Islam.

Historically, Russia continued to import cotton fabrics from Asia, mainly from China and Central Asia, for many centuries. Even after Russia started to export its cotton fabrics to Asia, it mainly imported them from Central Asia (Fig. 4). Nomadic or Turkish people in Russian territory needed cotton fabrics from Central Asia. Therefore, we must pay attention to the fact that Russia did not stop importing cotton fabrics from Asia, even after it exported its cotton fabrics to Asia. 


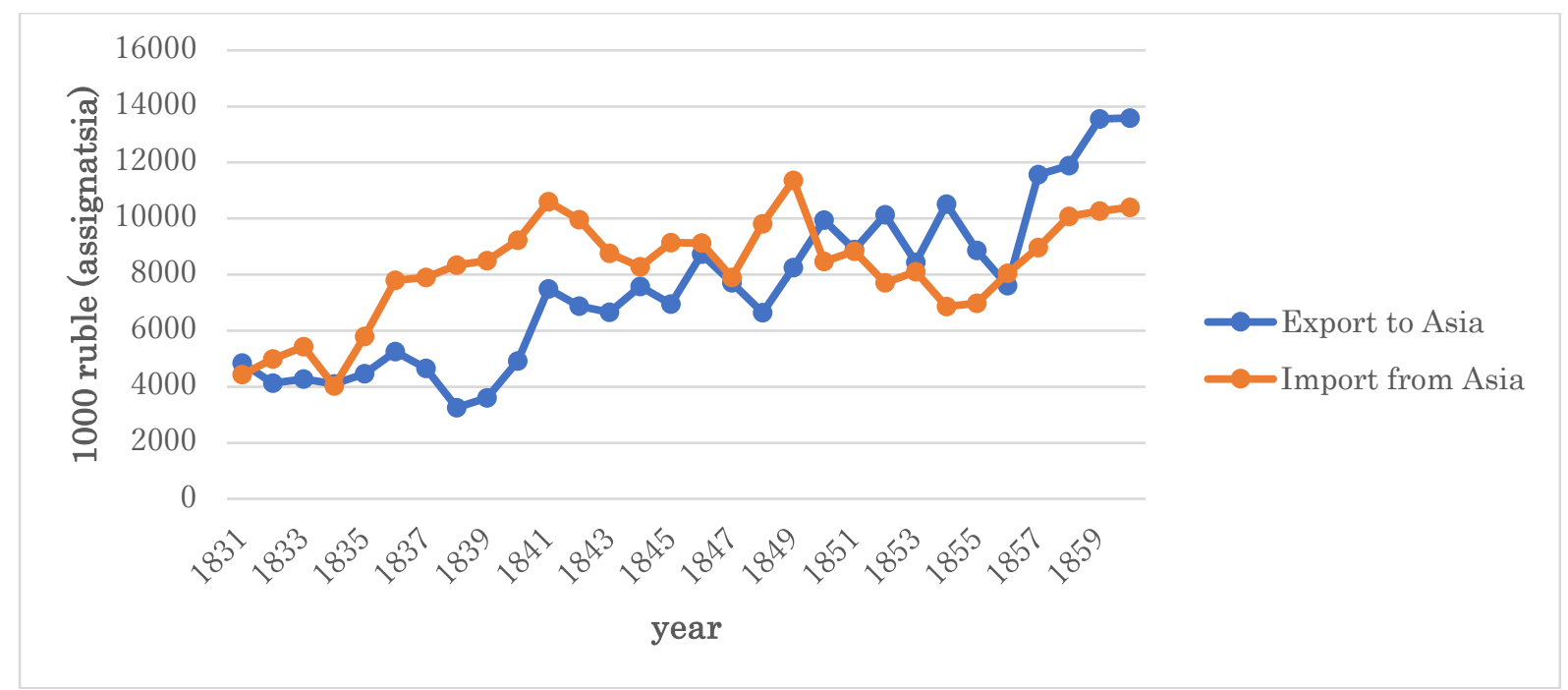

\section{Insert Figure 4}

Figure 4: Trade in cotton fabrics between Russia and Asia, 1831-1860. Source: Departament vneshney torgovli, 1832-1861.

\section{The Export of Russian Cotton Fabrics to Central Asia}

Russia exported fur to and imported cotton fabrics from Central Asia until the beginning of the nineteenth century. Then, the pattern of trade between the two regions changed. Following industrialization, in the first half of the nineteenth century, Russia started massproducing goods. Subsequently, it began to export cotton fabrics to Central Asia and import raw cotton and dyestuff from the region (Shiotani 1998, 41). Although fur exports generated revenue for the Russian government, these declined, and exports of Russian cotton fabrics increased. However, the revenue from cotton exports was less than that from fur. When the imports of raw cotton and dyestuffs from Central Asia increased, the Russian balance of trade with Central Asia shifted from surplus to deficit.

The increase in the import of raw cotton and dyestuffs from Central Asia was linked to the development of the Russian cotton industry, which required raw cotton. American cotton comprised 80 percent of cotton imports, with Central Asian cotton accounting for the remaining 20 percent. As the Russian cotton industry developed, imports of raw cotton increased from both America and Central Asia. Although the proportion of Central Asian 
cotton imports remained low, demand in the Russian household industry was high. Thus, Russian imports of raw cotton from Central Asia increased. Once Russian cotton fabrics were supplied to domestic fairs, printed cotton accounted for a large proportion of the sales of such fabrics (Melynikov 1846); demand was high as printed cotton was colorful. As dyestuffs were essential for the production of printed cotton, cochineal and madder imported from Bukhara were also important to the Russian dyeing business in the nineteenth century. Below, we describe the trade route between Central Asia (Bukhara) and Russia.

There were three trade routes between Russia and Bukhara (Ziyaev 1983, 3), which were used from the sixteenth to the nineteenth century. The first route was through West Siberia (Bukhara-Tobolsk), the second along the Volga River (Bukhara-Caspian Sea-AstrakhanNizhegorod Fair), and the third through the Ural region (Bukhara-Orenburg-Kazan) (Fig. 5). Historically, the first route was the main line between Bukhara and Siberia, which was connected by the Khanate of Sibir. The second route was the main route between European Russia and Bukhara after the sixteenth century. When Russian witnessed an increase in the import of raw cotton in the nineteenth century, the third route became imperative (Kommercheskaya Gazeta 1831, N87).

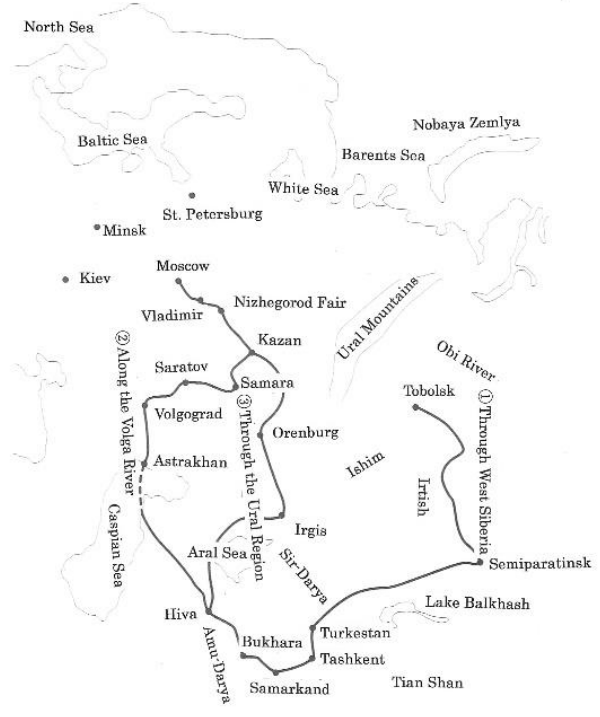




\section{Insert Figure 5}

Figure 5. Trade routes of Bukharan merchants. Source: Shiotani 2014, 146.

In the nineteenth century, Bukharan merchants exported raw cotton to Russia and imported cotton fabrics, which they transported via camels, horses, and mules (Kommercheskaya Gazeta 1836, N99). While horses and mules were used to transport goods over short distances, camels were used for transportation over long distances. When conducting trade with foreign countries, merchants organized caravans of camels that were loaded with commodities, with large caravans consisting of more than five thousand camels (Kommercheskaya Gazeta 1826, N71). They primarily transported commodities from Central Asia to Russia from fall to spring, because it was difficult to pass the steppes in Central Asia in the summer, due to intense heat and the presence of harmful insects (Kommercheskaya Gazeta 1840, N33). After caravans transported raw cotton from Central Asia to Russia, they returned with Russian cotton fabrics. The second route, along the Volga River, which connected Russia and Central Asia, was often used. However, after the imports of raw cotton increased, the third route, through the Ural region (via Orenburg), became the primary route (Kommercheskaya Gazeta 1843, N150). As the Volga River remained frozen during the winter, ships were not unable to navigate the river. As the route along Ural was a land route, it could be used even during the winter. Bukharan merchants usually unloaded in Orenburg and left for Central Asia with Russian commodities from there. From the middle of the nineteenth century, Orenburg became the base for trade between Russia and Central Asia.

Exports to Central Asia (Departament vneshney torgovli 1832-1861) were most stable in the 1830s when Russian cotton fabrics were exported to Asia. During that time, Vladimir province specialized in the production of cotton fabrics for peasants. Entrepreneurs in Vladimir exported their cotton fabrics to Central Asia through Bukharan merchants, to whom 
they sold their cotton fabrics at the Nizhegorod Fair (Baldin and Korkhova 2004, 193). In turn, Bukharan merchants not only engaged in trade, but also collected information on consumers' tastes in Central Asia and informed Russian entrepreneurs. This helped entrepreneurs understand the market and manufacture products suitable for local consumers. In this way, entrepreneurs in Vladimir established their brand in Central Asia (Kommercheskaya Gazeta 1832, N79). The cotton industry in the Vladimir regions continued to develop in the second half of the nineteenth century, and Vladimir became the center of the dyeing business for Russian peasants and consumers in Central Asia (Table 1).

\begin{tabular}{|r|r|r|l|r|r|r|r|r|}
\hline & \multicolumn{2}{|c|}{ Moscow } & \multicolumn{2}{c|}{ Vladimir } & \multicolumn{2}{c|}{ St. Petersburg } & \multicolumn{2}{c|}{ other cities } \\
\hline year & $\begin{array}{l}\text { number of } \\
\text { factories }\end{array}$ & production & $\begin{array}{l}\text { number of } \\
\text { factories }\end{array}$ & production & $\begin{array}{l}\text { number of } \\
\text { factories }\end{array}$ & $\begin{array}{l}\text { production } \\
\text { pumber of } \\
\text { factories }\end{array}$ & production \\
\hline 1866 & 57 & 16810 & 68 & 11666 & 6 & 3653 & & 5 \\
\hline$\%$ & & 49.2 & & 34.1 & & 10.7 & & 2033 \\
\hline 1879 & 42 & 36692 & 56 & 34350 & 7 & 11153 & 8 & 8190 \\
\hline$\%$ & & 40.6 & & 38 & & 12.3 & & 9.1 \\
\hline
\end{tabular}

\section{Insert Table 1}

Table 1. The production of the dyeing industry in Russia's main provinces, 1866-1869. Source: Arima 1987, 87. Unit of production: one million arshin.

When Russian cotton fabrics were exported to Central Asia, Russian commodities did not compete with local fabrics. There were two kinds of textile markets in Central Asia: the market for high-grade textiles, including silk and velvet, and that for low-grade textiles, including local cotton fabrics and ikat. Russian cotton fabrics belonged to neither of these two markets; it carved a niche for itself in the middle of the market. In those days, the local dress worn in Central Asia consisted of three kinds of clothes: a shirt, a long cloth, and a halato. The local rich class used Russian printed cotton as the lining of halatos.

There were two types of Russian printed cotton: red and multicolor printed cotton. We now focus on red printed cotton, which was dyed using madder. Russia imported this cotton from 
Central Asia before the eighteenth century. The color of red was considered holy in both Russia and Central Asia. During the Russian Revolution, the Russian Red Army raised a flag made of red printed cotton. From the seventeenth century, Russia imported such cotton from Central Asia. It successfully import-substituted the red printed cotton from Central Asia over three centuries.

Russia relied on America for its supply of raw cotton, but it faced a cotton supply crisis when it could not import it during the American Civil War. Russia wanted to import Central Asian cotton instead, but this was not suitable for its mills. Therefore, Russia attempted to transplant "Upland" American cotton and establish a supply base in Central Asia in the second half of the nineteenth century (Ter-Avaneshan 1956, 600). After Russia's experiments in Central Asia succeeded in 1883, it began to transplant American cotton in Bukhara, Fergana, Samarkand, and the Syr-Darya region, and increased the cultivation of American cotton.

\section{Cause for Innovation: Ongoing National Preference}

It was previously believed that the introduction of European science and technology caused industrialization. The representative view constitutes the Developmental Stage Theory. According to scholars, as England was the first industrialized country, latecomers often followed the English model of development. However, few studies have asked why Europe needed to assimilate industrialization (Riello 2013). ${ }^{2}$ According to the "common sense" of the West, industrialization is an a priori good. Therefore, its advance has never been questioned, for the question itself seemed nonsensical. The reason Russia succeeded in industrialization in the nineteenth century may have been its use of the European transatlantic

\footnotetext{
2 Although few scholars connected industrialization in England with the import substitution of Indian printed cotton, G. Riello (2013) did refer to the connection.
} 
trade and European science and technology. Therefore, Russia's need to assimilate industrialization could be attributed to its desire to catch up with other industrialized countries. However, this explanation would only be partially correct. The other part of the answer lies with Russia's desire to overcome its environmental constraints and to importsubstitute its favored commodity, red printed cotton.

Russian people adored red printed cotton from Central Asia and eventually learned the dyeing technique from Bukharan artisans and achieved import substitution. Russian peasants then began to use the red printed cotton made in Russia. By the end of the eighteenth century, England's modern cotton industry influenced that of Russia.

There were two kinds of red cotton in Russia at that time: European red and Central Asian red (Fig. 6). While European red was an imitation of the fabric from England or the Alsace region (Mulhouse), Central Asian red imitated Central Asian printed cotton that Russia imported prior to the eighteenth century.

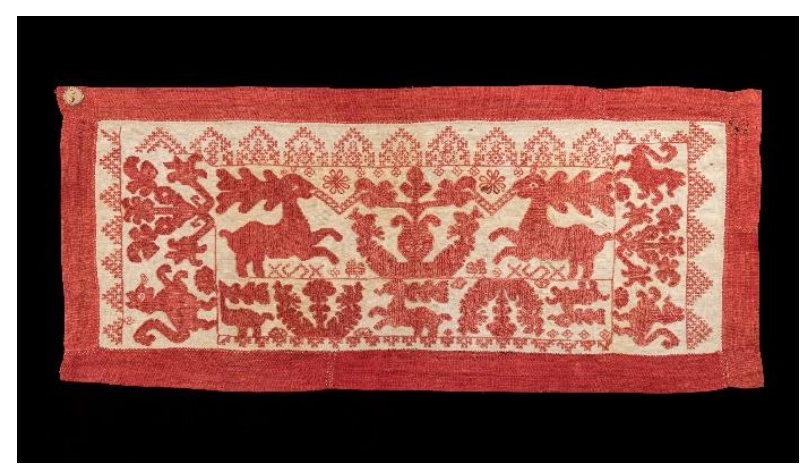

\section{Insert Figure 6}

Figure 6. Border, late eighteenth century, Russia. Brooklyn Museum Costume Collection at The Metropolitan Museum of Art (New York), Gift of the Brooklyn Museum, 2009; Gift of Mrs. Edward S. Harkness in memory of her mother, Elizabeth Greenman Stillman, 1931

Russia exported printed cotton in both European and Central Asian red. According to extensive research on Soviet ethnology, the printed cotton of Central Asian red was widely 
accepted in local markets of Central Asia. Local consumers used it as the lining of the harat (Sazanova 1989, 39).

The Russian import substitution of Central Asian red printed cotton spanned three centuries. Modern European knowledge liberated Russia from the constraints of nature. Russia import-substituted the red printed cotton from Central Asia, which Russian people adored prior to the eighteenth century. As a result, Russia was able to export its red printed cotton to Central Asia for three centuries.

It should be emphasized that an appreciation and preference for Indian printed cotton promoted industrialization in Europe (Kawakatsu 1991). Originally, environmental conditions in Europe were unsuitable to sustain cotton cultivation. However, Europeans' desire to acquire Indian printed cotton led to an international division of labor and improvement of its science and technology. Import substitution of this cotton in Europe took place over three centuries. It is difficult to identify the causal mechanism of industrialization in Europe. However, it is quite clear that Europe began to import cotton from the Middle East and America to overcome its natural constraints. Europe then applied chemistry to dyeing by developing the roller dyeing machine, which also improved productivity. If we endeavor to understand these innovations comprehensively, we can conclude that Europe was industrialized for the import substitution of Indian printed cotton. Even at the beginning of the nineteenth century, English designers learned from patterns of Indian clothes (Fig. 7). I think that English people came to appreciate Indian culture through printed cotton. 


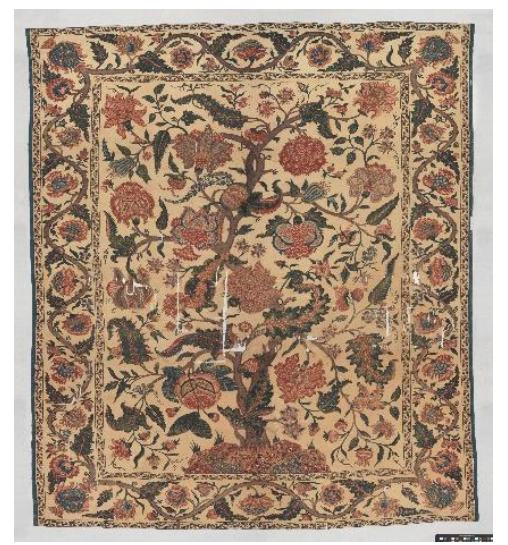

\section{Insert Figure 7}

Figure 7. Bed cover (Palampore), eighteenth century, India. Metropolitan Museum (New York). Purchase, Bequest of George Blumenthal and Gift of Indjoudjian Freres, by exchange, and The Friends of the Islamic Department Fund, 1982.

Even though Russia established its cotton industry in the nineteenth century, it exported cotton fabrics to Asia, but not to Europe. Scholars have attributed this to inferior products due to Russia's relatively low-level technology. Although I agree that Russian technology was inferior to that of Europe, it is noteworthy that if there was no appreciation of Indian printed cotton, there would not have been a desire to imitate the fabric and export it to India. As Russia desired red printed cotton from Central Asia, it endeavored to import substitute printed cotton since the eighteenth century. After Russia imported the technology and materials from Europe in the nineteenth century, it exported manufactured cotton fabrics to Asia, and Russian commodities started to be accepted in Central Asia. In summary, Russia initially imported cotton fabrics from Central Asia, and Central Asia eventually became its market for commodities in the nineteenth century. At that time, Bukharan merchants (Central Asia) promoted Russian trade with Central Asia through their distribution network.

Transportation modes such as the steamship and railroads, powered by the steam engine, appeared in the nineteenth century. Innovation in distribution followed this 
innovation in production. The former changed the means of long-distance trade, which was previously dependent on animals and natural conditions. Russia used the commercial network of Asian merchants and exported Russian cotton fabrics to Central Asia in the first half of the nineteenth century. However, after the introduction of the steam engine to distribution, highspeed transportation received a boost (Fig. 8). When railroads were built in Russia, the yearly trade cycle followed by Asian merchants lost vitality, and modern modes of transportation replaced the extensive distribution networks of ethnic merchants. Thus, export of Russian commodities by Asian merchants was the transitional form in the nineteenth century, when the steam engine was not used for distribution. In the second half of the nineteenth century, Russia successfully transplanted "Upland" American cotton into Central Asia and used railroads to transport this cotton from Central Asia to Moscow.

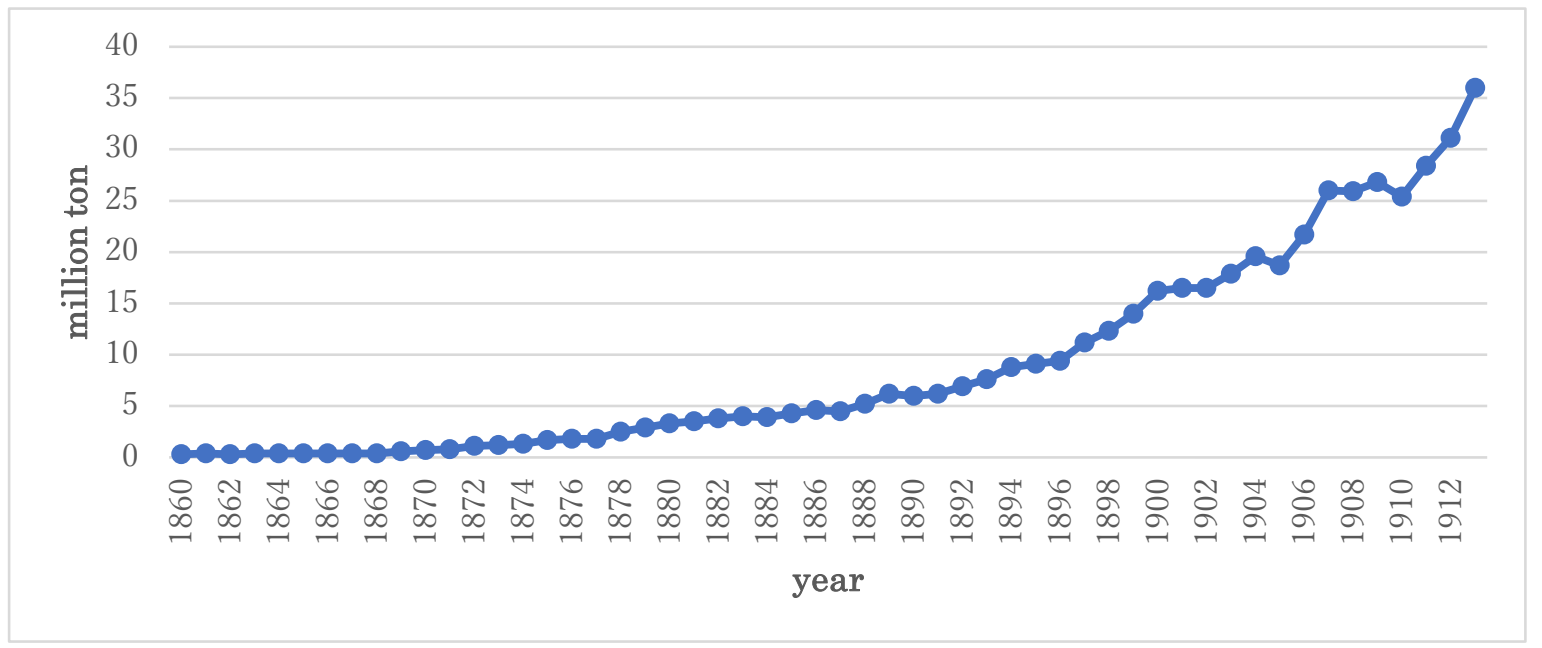

Figure 8. Production of coal in Russia, 1860-1913. Source: Mitchell 1998, 431.

According to my research, both Europe ${ }^{3}$ and Russia had a desire to import commodities (printed cotton) from Asia because their environmental conditions hampered the production

${ }^{3}$ In this study, "Europe” mainly consists of Belgium, England, and France. 
of cotton fabrics. Europe successfully import-substituted its desired commodities by constructing a transatlantic trade system and applying scientific methods to industries.

Europe established its superiority through the transformation of energy sources from nature to fossil fuels (the steam engine). This increased its productivity and ability to transport goods. As a result, it had a surplus of commodities and sought to capture materials and markets abroad. After Russia learned of European experiences (the trade system and the use of science and technology), it also achieved early industrialization in the first half of the nineteenth century. Like Europe, Russia also wanted to gain the market and materials in foreign countries. When Russia annexed Central Asia, it reduced its dependence on Europe with the intention of building a closed economy within Russian territory.

As previously highlighted, industrialized countries had unfavorable natural circumstances in comparison with Asia. However, as Europe had an ongoing demand for and appreciation of Indian commodities, it tried to find ways of import-substituting them. To this end, Europe created its science and technology, built a transatlantic trade system, and subsequently succeeded in import-substituting Indian printed cotton. Similarly, Russia also tried to import-substitute the red printed cotton that it received from Central Asia and realized industrialization. Thus, it can be concluded that when a certain national ongoing appreciation or preference persists for a long time (in this case, three centuries), even if circumstances are unfavorable, obstacles can eventually be overcome and the object in question obtained, even if indirectly. As Russia continued to import printed cotton from Central Asia for a long time, it appreciated Central Asian red printed cotton. Ongoing appreciation for the object (culture) helped them innovate and utilize European modern experiences. In this case, Russia's desire to acquire red printed cotton from Central Asia led to the development of its modern cotton industry. 


\section{References}

Arima Tatsuro. 1973. Rosiya Kogyoshi Kenkyu [The Study of Russian Industrial History]. Tokyo: University of Tokyo Press.

Arima Tatsuro. 1987. “Teisei Rosiya menkogyo no hatten kozo (1)” [The Developmental Structure of the Cotton Industry in Imperial Russia]. Niigata daigaku Keizai ronshu 43 (1): 74-89.

Baldin, K. E., and L. A. Korkhova. 2004. Ot kustarnogo sela k Industrialynomu «Megapolis», Ocherki ictorii tekstilynoiy promyshlennosti v sele Ivanove-gorode IvanovoVoznesenske [From the Village of Cottage Industry to Industrial Megapolis, the Historical Study of the Textile Industry in Ivanovo village-Ivanovo-Voznesensk City]. Ivanovo: Novaya ivanovskaya gazeta.

Bogoroditskaya, N. A. 1989. Nizhegorodskaya Yarmarka-Krupneyshiy Tsentr Vnutrenney $i$ Mezhdunarodnoy Torgovli v Pervoy Polovine XIX veka. [Nizhegorodo Fair-The Largest Center of Domestic and International Trade in the First Half of the 19th Century]. N. Novgorod: B.i.

Chapman, S. D. 1985. "Quantity versus Quality in the British Industrial Revolution: The Case of Printed Textiles." Northern History 21: 175-192.

Departament Vneshney Torgovli. 1825-1860. Kommerchskaya Gazeta [Commercial Newspaper]. Saint Petersburg.

Departament Vneshney Torgovli. 1825-1866. Zhurnal Manufaktur i Torgovli [Journal of Manufacture and Trade]. Saint Petersburg.

Departament vneshney torgovli. 1832-1861. Gosudarstvennaya vneshnyaya torgovlya $v$ raznykh ee vidakh, za 1831-1860 [Russian Foreign Trade from 1831 to 1860 from Many Angles]. Saint Petersburg.

Fukasawa Katsumi. 2007. Shonin to Sarasa [Merchants and Printed Cotton]. Tokyo: University of Tokyo Press.

Industriya. 1910. Tekstilynoe Delo v Rossii [Textile Business in Russia]. Odessa: Poryadok. Kawakatsu Heita. 1991. Nihon Bunmei to Kindai Seiyo, Sakoku Saiko [Japanese Civilization and Modern Europe: Reconsideration of the Closed Japan]. Tokyo: NHK Publisher. Komatsu Hisao. 1983. "Bukhara to Kazan" [Bukhara and Kazan]. In Nairiku Asia, Nishi Asia 
no Shakai to Bunka [Inner Asia: The Society and Culture in Western Asia], edited by Mori Masao, 481-500. Tokyo: Yamakawa Publishing.

Kommerchskaya Gazeta. 1826. 8 sentyabrya, N71, 2.

Kommerchskaya Gazeta. 1831. 31 oktyabrya, N87, 646.

Kommerchskaya Gazeta. 1832. 1 oktyabrya, N79, 613.

Kommerchskaya Gazeta. 1836. 19 avgusta, N99, 392.

Kommerchskaya Gazeta. 1840. 16 marta, N33, 130-131.

Kommerchskaya Gazeta. 1843. 23 dekabrya, N150, 598.

Meller, S. 2007. Russian Textiles: Printed Cloth for the Bazaars of Central Asia. New York: Abrams.

Melynikov, P. 1846. Nizhegorodskaya Yarmarka v 1843, 1844 i 1845 godakh [Nizhegorod Fair in 1843, 1844, and 1845]. Nizhniy-Novgorod: Gubernskaya tipografiya.

Mitchell, B. R. 1998. International Historical Statistics: Europe 1750-1993. London: Macmillan.

Ostroukhov, P. A. 1972. "Nizhegorodskaya Yarmarka v 1817-1867gg” [Nizhegorod Fair from 1817 to 1867]. Istoricheskie Zapiski [Historic Memoirs]. Vol. 90. Moscow.

Panossian, R. 2006. The Armenians: From Kings and Priests to Merchants and Commissars. New York: Columbia University Press.

Riello, G. 2013. Cotton: The Fabric That Made the Modern World. Cambridge: Cambridge University Press.

Sano Takahiko. 1978. Mulhouse Senshoku Bijutukan [Dyeing Museum in Mulhouse], vol. 1, France no Senshoku [Dyeing in France]. Tokyo: Gakushu kenkyu-sha.

Sazanova, M. V. 1989. Traditsionnaya odezhda narodov Sredney Azii i Kazakhstana [National Traditional Clothes in Central Asia and Kazakhstan]. Moscow: Nauka.

Shiotani Masachika. 1998. "Russian Cotton Industry and Export of Russian Cotton Fabrics to Asia in the First Half of the 19th Century." Keizaigaku Zasshi 99 (3-4): 38-59.

Shiotani Masachika. 2000. "Rossiya na rynke khlopchatobumazhnykh tkaney Azii v pervoy polovine X IX v" [Russia in the Asian market of Cotton Textiles in the First Half of the 19th Century]. Gumanitarnye nauki v Sibiri [Humanities in Siberia], no. 2: 26-31.

Shiotani Masachika. 2009. "Strukturnoe izmenenie assortimenta tovarov na Nizhegorodskoy yarmarke s 1828 po $1860 \mathrm{~g}$ " [Structural Change of Assortments of Commodities in Nizhgorod Fair from 1828 to 1860]. Gumanitarnye Issledovabiya Vnutrenney Azii [Humanity Studies of Inner Asia], nos. 4-5: 70-88. 
Shiotani Masachika. 2014. Rosiya Mengyo Hatten no Keiki, Rosiya sarasa to Ajia Shonin [The Development of the Cotton Industry in Russia: Russian Printed Cotton and the Asian Merchants]. Tokyo: Chisen Shokan.

Shiotani Masachika. 2019. "The Export of Russian Cotton Fabrics and the Commercial Network of Asian Merchants in the First Half of 19th Century. Part 2." Vestnik Novosibirsk State University (Russia). Series: History and Philology 18 (1): History: $41-55$.

Silin, E. P. 1947. Kyakhta v 18 veke [Kyakhta in the 18th Century]. Irkutsk: Irkutskoe oblastnoe izdatelystva.

Solovyev, V. L., and M. D. Boldyreva. 1987. Ivanovskie Sitsy [Printed Cotton in Ivanovo]. Moscow: Legprombytizdat.

Sugiyama Masaaki. 2010. Kubirai no Chosen [The Challenge of Kublai Khan]. Tokyo: Kodansha.

Ter-Avaneshan, D. V. 1956. "K istorii Khlopkovodstva v SSSR" [History of Cotton Cultivation in the Soviet Union]. Materialy po nstorii zemledeliya SSSR [Materials of Agricultural History in the Soviet Union]. Sbornik 2. Moscow: Izdatelystvo akademii nauk SSSR.

Yamauchi Masayuki. 2009. Surutan Gariev no Yume, Isulamu sekai to Russia Kakumei [The Dream of Mirsaid Sultan-Galiev: The Islamic World and the Russian Revolution]. Tokyo: Iwanami Publishing.

Yatsunsky, V. K. 1974. “The Industrial Revolution in Russia.” In Russian Economic Development from Peter the Great to Stalin, edited by W. L. Blackwell, 111-135 New York: New Viewpoints.

Yatsunskiy, V. K. 1979. “Krupnaya promyshlennosty Rossii v 1790-1860gg” [Russian Large Industry from 1790 to 1860). In Ocherki ekonomicheskoy istorii Rossii pervoy poloviny 19 veka [The Study of Russian Economic History in the First Half of the 19th Century], edited by M. K. Rozhkova, 118-220 Moscow: Izdatelystvo sotsialynoekonomicheskoy literatury.

Ziyaev, Kh. Z. 1983. Ekonomicheskie svyazi Sredney Azii s Sibiryyu v X VI-XIX vv.

[Economic Connections between Central Asia and Siberia from the 14th to the 16th Century]. Tashkent: Izdatelystvo «fan». 